\title{
Reformulasi Pengaturan Tanggung Jawab Perusahaan Sebagai Ikhtiar Pemenuhan Hak Atas Lingkungan Hidup
}

\section{Moch Andry Wikra Wardhana Mamonto ${ }^{1}$}

${ }^{1}$ Ilmu Hukum, Fakultas Hukum, Universitas Muslim Indonesia.

Email Correspondensi: moch.andrymamonto@umi.ac.id

No. Handphone Correspondensi: (+62) 85243637454

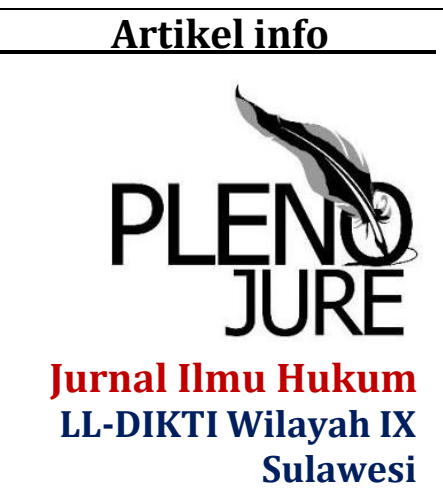

Artikel history:

Received; 10-03-2021

Revised:18-04-2021

Accepted;20-04-2021

\footnotetext{
Keywords:

Tanggung jawab

perusahaan;
}

\begin{abstract}
Abstrak. Artikel ini bertujuan mengidentfikasi sejauh mana peraturan perundang-undangan tentang tanggung jawab perusahaan menjadi instrumen menjaga lingkungan dan pembangunan berkelanjutan. Metode penelitian yakni penelitian hukum normatif dengan sifat penelitian deskriptif-eksplanatoris. Peraturan tanggung jawab perusahaan terhadap lingkungan bersifat parsial baik secara horizontal dan vertikal, keseluruhan peraturan belum menunjukkan sinkronisasi serta belum diarahkan untuk memberikan perlindungan lingkungan dan menjaga keberlanjutan pembanguna. Oleh karenanya, penting dilakukan reformulasi dengan menegaskan tanggung jawab perusahaan pada aspek lingkungan melalui penetapan jumlah anggaran setiap tahunnya diperuntukan perbaikan dan pelestarian lingkungan.
\end{abstract}

Abstract. This article aims to identify the extent to which laws and regulations on corporate responsibility are instruments of protecting the environment and sustainable development. The research method is normative legal research with descriptive-explanatory data analysis techniques. The regulations on corporate responsibility for the environment are partial both horizontally and vertically, all regulations have not shown synchronization and have not been directed to provide environmental protection and maintain sustainable development. Therefore, it is important to carry out reformulation by emphasizing the company's responsibility for environmental aspects by determining the amount of the budget each year for environmental improvement and preservation. 


\section{Perlindungan \\ lingkungan; \\ Lingkungan \\ Hidup; \\ Pembangunan \\ berkelanjutan;}

\section{PENDAHULUAN}

Dunia industri terus mengalami perkembangan, pada tahun 2017 dirilis bahwa 10 (sepuluh) tahun terakhir di Indonesia terdapat sekitar 3,98 (tiga koma sembilan puluh delapan) juta perusahaan mencakup perusahaan yang bergerak dibidang pemanfaatan sumber daya alam. ${ }^{1}$ Berdalil pada data tersebut, menunjukan bergairahnya dunia industri di Indonesia. Secara konsep keberadaan perusahaan ibaratkan 2 (dua) sisi mata uang, satu sisi memberikan dampak posistif berupa pemenuhan kebutuhan masyarakat, pengembangan ilmu pengetahuan dan teknologi dan melahirkan kesejahteraan baru, sedangkan sisi negatif menguras dan mengikis ketersediaan sumber daya alam, kualitas kesehatan fisik masyarakat, kondisi sosial kehidupan masyarakat dan kerusakan lingkungan. ${ }^{2}$ Jika diperinci, dampak negatif dari keberadaan industri meliputi: limbah industri menyebabkan polusi tanah, pencemaran udara, pencemaran air dan kerusakan pesisir dan laut. ${ }^{3}$

Bertalian dengan dampak kerusakan lingkungan, tercatat kegiatan industri pada aspek pemanfaatan sumber daya alam menjadi penyumbang tertinggi penyebab kerusakan lingkungan mencapai angka 70\% (tujuh puluh) persen. ${ }^{4}$ Membaca potret kerusakan lingkungan, meneguhkan pandangan tentang menurunnya kualitas lingkungan hidup yang menyebabkan terancamnya keberlangsungan hidup manusia dan makhluk hidup lainnya, dalam perspektif konstitusional fenomena ini berpotensi menjadi penyumbat pemenuhak hak warga negara memperoleh lingkungan hidup yang baik dan sehat sebagaimana diamanatkan Pasal 28H ayat (1) Undang Undang Dasar Negara Republik Indonesia Tahun 1945 (selanjutnya disingkat UUD NRI 1945), dalam konteks komitmen global fenomena tersebut berpotensi menjadi penyumbat pencapaian tujuan ke 15 pembangunan berkelanjutan yaitu melindungi, merestorasi dan meningkatkan pemanfaatan berkelanjutan ekosistem daratan, mengelola hutan secara lestari, menghentikan penggurunan, memulihkan degradasi lahan, serta menghentikan kehilangan keanekaragaman hayati yang ditetapkan melalui Peraturan Presiden Nomor 59 Tahun 2017 tentang Pelaksanaan Pencapaian Tujuan Pembangunan Berkelanjutan..

Berpijak pada uraian-uraian tentang dampak negatif dari eksistensi industri memberikan pencerahan bahwa keberadaan tanggung jawab sosial

\footnotetext{
${ }^{1}$ Detik Finance, Jumlah Perusahaan 10 Tahun Terakhir di Indoensia, <https://finance.detik.com/beritaekonomi-bisnis/d-3485474/ada-398-juta-perusahaan-baru-di-ri-dalam-10-tahun-terakhir> (diakses, 14 Maret 2020)

${ }^{2}$ Samuel Ronatio Adinugroho, Budiharto dan Joko Priyono. (2017). Pelaksanaan Tanggung Jawab Sosial dan Lingkungan PT. Pertamina Semaran (Persero) Ditinjau Dari Undang-Undang No 40 Tahun 2007 Tentang Perseroan Terbatas. Diponegoro Law Journal. 6(1). 1-14. Hal. 9.

${ }^{3}$ Ita Rustiati Ridwan, Dampak Industri Terhadap Lingkungan dan Sosial, Materi Kuliah PGSD UPI, Serang Banten, file:///Users//Downloads/1528-2745-1-SM.pdf (diakses, 25 Juni 2020).

4 Kompas.com, 70 Persen Kerusakan Lingkungan akibat Operasi Tambang, https://regional.kompas.com/read/2012/09/28/17313375/70.Persen.Kerusakan.Lingkungan.akibat.Oper asi.Tambang (diakses, 20 Juli 2020)
} 
perusahaan merupakan refleksi kritis moralitas dalam kegiatan ekonomi atau disebut etika bisnis. ${ }^{5} \mathrm{Hal}$ ini senafas dengan pergeseran pendulum orientasi dunia bisnis, mulanya hanya berdasar pada konsep single bottom line atau berorientasi profit semata, bergeser dengan juga berfokus terhadap masyarakat dan lingkungan sekitar. ${ }^{6}$ Didalilkan bahwa perusahaan tidak hanya mengejar keuntungan (profit) semata, tetapi juga harus selalu memperhatikan orang-orang (people) baik di dalam maupun luar perusahaan, dan lingkungannya (planet). ${ }^{7}$

Semua mahfum, secara teoretik dalam konteks penyelenggaraan negara ikhtiar-ikhtiar pemerintah mencapai tujuan bernegara dilakukan melalui penggunaan instrumen hukum mencakup tujuan pemenuhak hak konstitusional memperoleh lingkungan hidup baik dan sehat. Hal ini seturut dengan ajaran begawan hukum kelahiran Lincoln (Roscoe Pound) yaitu "law is tool social engineering" ${ }^{8}$ melalui pilihan-pilihan kebijakan resmi negara atau politik hukum 9 . Senafas, secara spesifik dan tegas Guningham dan Graboskky bersabda bahwa instrumen hukum memainkan peran penting dalam mengarahkan perbaikan lingkungan. ${ }^{10}$

Berbeda dengan negara-negara lainnya terutama negar-negara maju yang memandang tanggung jawab perusahaan yang dikenal dengan istilah Corporate Social Responsibility identik dengan sifatnya responsibility sebagaimana gagasan awal tanggung jawab sosial yang diperkenalkan dalam konteks global oleh Carnegie seorang konglomerat kebangsaan Amerika pemilik perusahaan U.S Stell secara garis besar memberikan pencerahan bahwa tanggung jawab sosial didasarkan pada dua prinsip yaitu: prinsip amal dan pengurus harta orang lain. ${ }^{11}$ Indonesia memilih sikap berbeda dengan menggeser tanggung jawab perusahaan menjadi liability, tidak berhenti sampai disitu pergeseran tentang konsep tanggung jawab perusahaan dilakukan dengan mufakat bahwa tanggung jawab perusahaan tidak hanya meliputi tanggung jawab sosial semata, namun juga tanggung jawab lingkungan sebagaimana terkristalisasi dalam rumusan ketentuan umum Undang- Nomor 40 Tahun 2007 tentang Perseroan Terbatas. ${ }^{12}$

Selain berikhtiar dengan mufakat pergeseran pendulum karakter tanggung jawab perusahaan melalui undang-undang perseroan terbatas guna memenuhi tanggung jawab negara atas hak lingkungan. Ikhtiar juga dilakukan melalui beberapa kebijakan resmi negara.

\footnotetext{
${ }^{5}$ Angeli Weller. (2017). Exploring Pratitioners' Meaning of "Ethics”, “Compliance”, dan "Corporate Social Responsibility" Practices: A Communities of Practice Perspective, Business and Society. 1-27. Hal. 16

6 Ioannis E. Nikolaou, Konstatinos I. Evangelinos dan A. Allan. (2012). A Reverse Logistics Social Responsibility Evaluation Framework Based on the Triple Bottom Line Approach, Journal of Cleaner Production, 1-12. Hal. 8.

${ }^{7}$ Cita Insaniah Muhammad, Santoso Tri Raharjo dan Risan Resnawaty. (2018). Pelaksanaan Corporate Social Responsibility PT. Indonesia Power UPJP Kamojang, Social Work Jurnal, 2018, 8(2). 195-202. Hal. 199.

${ }^{8}$ Umbu Rauta and Ari Siswanto. (2018). Revitalization of Adat Law as an Instrument pf Social Engineering in Central Sumba, Jurnal Dinamika Hukum, 18(3). 348-356. Hal. 351. Lihat juga Atip Latipulhayat. (2014). Roscoe Pound, Khazanah Padjajaran Jurnal Ilmu Hukum, 1(2). 413-424. Hal. 417.

${ }^{9}$ Moch Andry W W Mamonto. (2019). Legal Politics of Simplifying Political Parties in Indonesia (Case Study of 2004-2014), Substantive Justice Jurnal of Law, Vol 2, No. 1, 1-20. Hal, 9.

10 Neil Gunningham. (2009). The New Collaborative Enviromental Governance: The Localization of Regulation, Journal of Law and Society, 36(1). 145-166. Hal, 157.

11Janowski Andrzej. (2020). Philanthropy and the Contribution of Andrew Carnegie to Corporate Social Responsibility, MDPI, 13(155). 1-26. Hal, 13.

${ }^{12}$ Nova Mandasari. (2016). Urgensi Tanggung Jawab Sosial Perusahaan Dari Bersifat Sukarela (Voluntary) Menjadi Wajib (Mandatory), Jurnal Rechtsvinding, 1-4. Hal, 2.
} 
Berdalil pada uraian-uraian di atas, maka penelitian ini bertujuan untuk memotret sinkronisasi dan harmonisasi norma baik secara horizontal dan vertikal guna mendudukkan tanggung jawab perusahaan sebagai instrumen perlindungan lingkungan dan pembangunan berkelanjutan..$^{13}$ Oleh karenanya, keberadaan beberapa peraturan perundang-undangan yang relevan menjadi jantung artikel tersebut.

\section{METODE}

Penelitian ini menggunakan tipe penelitian hukum normatif. Berfokus menelaah bahan hukum primer berupa peraturaan perundang-undangan baik secara horizontal dan vertikal yang memiliki korelasi dengan pengaturan tanggung jawab perusahaan atas hak lingkungan sehat dan pembangunan berkelanjutan, serta bahan hukum sekuder berupa buku dan jurnal yang memiliki korelasi dengan pengaturan tanggung ajawab perusahaan atas lingkungan sehat dan pembangunan berkelanjutan. ${ }^{14}$ Sifat penelitian ini deskriptif-eksplanatoris.

\section{HASIL DAN PEMBAHASAN}

Lentera ikhtiar sinkronisasi dan harmonisasi peraturan perundangundangan dimulai dengan memeriksa konstitusi untuk memastikan konstitusionalitas setiap norma yang diderivasi dari norma dasar (Undang Undang Dasar Negara Republik Indonesia Tahun 1945) atau norma tertinggi dalam sistem norma di Indonesia. ${ }^{15}$

Semua mahfum bahwa salah satu sendi utama penyelenggaraan ketatanegaraan Indonesia didasarkan pada hukum, ${ }^{16}$ jika tautkan dengan teori konstitusi, maka dikehendaki keseluruhan sistem hukum pada suatu negara didasarkan pada konstitusi. ${ }^{17} \mathrm{Hal}$ ini seturut dengan ajaran Kelsen (stufenbau theorie) ${ }^{18}$ yang telah diterima sebagai dalil dalam mengkonstruksi peraturan perundang-undangan artinya salah satu syarat wajib pembentukan peraturan perundang-undangan memperhatikan tingkatan setiap norma mencakup norma keseluruhan norma tentang pemanfaatan sumber daya alam, perlindungan lingkungan dan pembangunan berkelanjutan. Kehendak pemerintah mendudukkan Undang Undang Dasar Tahun 1945 sebagai norma tertinggi dalam sistem ketatanegaraan Indonesia terjelma melalui Pasal 7 dan Pasal 8 Undang-Undang Nomor 12 Tahun 2011 tentang Pembentukan Peraturan Perudang-Undangan yang telah diubah menjadi Undang-Undang Nomor 15 Tahun 2019 tentang Perubahan Atas Undang-Undang Nomor 12 Tahun 2011 tentang Pembentukan Peraturan Perundang-Undangan.

\footnotetext{
${ }^{13}$ Susilowati Suparto, dkk. (2016). Harmonisasi dan Sinkronisasi Pengaturan Kelembagaan Sertifikasi Halal Terkait Perlindungan Konsumen Indonesia, Mimbar Hukum, 28(3). Hal, 428-436.

${ }^{14}$ Andika Parwira Buana, Tria Abriana Ma'ruf dan Aan Aswari. (2019). Harmonisasi Peraturan PerundangUndangan terhadap Bentuk Perjanjian Melalui Telamarketing, Pleno Jure, 9(2), 47-59. Hal, 55.

${ }^{15}$ Nur Chanifah Saraswati dan Encik Muhammad Fauzan, Konstitusionalitas Peraturan Perundang-Undangan Berbasis Syariah Di Indonesia. (2019). Simposium Hukum Indonesia, 1(1). 496-510, Hal, 502.

${ }^{16}$ Jefry Alexander Ch. Likadja. (2015). Memaknai "Hukum Negara (Law Throught State) dalam Bingkai

"Negara Hukum (Rechstaat)", Hassanudin Law Review. 1(1). 75-86, Hal, 77.

${ }^{17}$ Kusnu Goeniadhie Slamet, (2004), Harmonisasi Hukum dalam Perspektif Perundang-Undangan, Jurnal Hukum, 27(11), 82-96, Hal, 93.

${ }^{18}$ FX. Adji Sametko. (2019). Menelusuri Akar Pemikiran Hnas Kelsen Tentang Stufenbautheorie Dalam Pendekatan Normatif-Filosofis, Jurnal Hukum Progresif, 7(1), 1-19, Hal, 11.
} 
Bertalian dengan kegiatan pemanfaatan sumber daya alam, dalam kerangka Undang Undang Dasar Negara Republik Indonesia Tahun 1945 memperoleh legitimasi dan dalil konstitusional melalui amanat Pasal 33 ayat (3) bahwa bumi dan air dan kekayaan alam dikuasai oleh negara dan dipergunakan sebesarbesarnya untuk kemakmuran rakyat. Berdalil pada amanah pasal tersebut, memberikan pencerahan dan menjadi pijakan mengaminkan bahwa kegiatankegiatan industri atas pemanfaatan sumber daya alam ialah konstituional. Kendatipun demikian, kegiatan pemanfaatan sumber daya alam wajib dilakukan berdasar batas-batas yang diamanatkan Undang-Undang Dasar Negara Republik Indonesia Tahun 1945 melalui rumusan Pasal 33 ayat (4) bahwa kegiatan pemanfaatan sumber daya alam harus melindungi lingkungan hidup dengan memperhatikan keberlanjutan dan berwawasan lingkungan.

Adapun rumusan norma dasar yang memuat semangat pembatasan atas pemanfaatan sumber daya alam, sejalan dengan fungsi konstitusi yaitu fungsi pembatasan kekuasaan, ${ }^{19}$ dapat dipahami norma ini memiliki semangat bahwa pemberian izin berisikan hak atas pemanfaatan sumber daya alam wajib disertai dengan pemberian kewajiban atas dampak dari kegiatan tersebut. Keberadaan norma yang memberikan kewajiban memperhatikan perlindungan lingkungan hidup guna menjaga keberlanjutannya mencerminkan kehendak pemerintah untuk memenuhi hak atas lingkungan hidup yang baik dan sehat sebagaimana amanat Pasal $28 \mathrm{H}$ ayat (1). ${ }^{20}$

Eksistensi pasal yang mengamanatkan pemenuhan hak memperoleh lingkungan hidup yang baik dan sehat senafas dengan buah konferensi Stockholm yaitu jaminan atas hak memperoleh lingkungan hidup yang bersih dan sehat sebagai hajat meminimalisir dampak atas penurunan fungsi lingkungan. ${ }^{21,22}$ Masuknya hak atas lingkungan hidup sebagai hak asasi manusia merupakan perkembangan doktrin hak asasi manusia generasi ketiga dari hasil kompromi dari doktrin hak asasi manusia generasi pertama dan generasi kedua. ${ }^{23}$

Di Indonesia, jaminan atas lingkungan sehat dan bersih dalam konstitusi cerminan atas pemaknaan Green Constitution atau upaya mempertegas konstitusionalitas norma hukum lingkungan di Indonesia. ${ }^{24}$ Oleh karenanya, berpijak pada uraian bangunan norma dasar penyelenggaraan praktik ketatanegaraan memberikan guide bahwa meskipun pemanfaatan atas bumi dan air dan kekayaan alam dikuasai oleh negara adalah konstitusional, ${ }^{25}$ akan tetapi dalam pemanfaatan sumber daya alam negara harus memiliki komitmen untuk melindungi dan memenuhi hak asasi manusia atas lingkungan hidup serta pembangunan berkelanjutan melalui penderivasian norma-norma yang sejalan dengan sistem norma tertinggi.

\footnotetext{
${ }^{19}$ Sri Soemantri, (1996) Fungsi Konstitusi Dalam Pembatasan Kekuasaa, Ius Quia Iustum Law, 6(3), 1-6, Hal, 4.

${ }^{20}$ Indonesia, Undang Undang Dasar Negara Republik Indonesi Tahun 1945, Pasal 28

${ }^{21}$ Ahmad Jazuli. (2015). Dinamika Hukum Lingkungan Hidup Dan Sumber Daya Alam Dalam Rangka Pembangunan Berkelanjutan. Rechtsvinding. 4(2), 181-197, Hal. 194.

22 Triansyah, W., Risma, A., \& Aswari, A. (2020). Alih Fungsi Lahan Sawah Tanah Redistribusi yang Diberikan Pemerintah. Qawanin Jurnal Ilmu Hukum, 1(1), 1-26. Hal, 23.

${ }^{23}$ Abdurahman Supardi Usman. (2018). Lingkungan Hidup Sebagai Subejk Hukum: Redefinisi Relasi Hak Asasi Manusi dan Hak Asasi Lingkungan Hidup Dalam Perspektif Negara Hukum. Legality, 26(1), 1-16, Hal. 8. ${ }^{24}$ I Gede Yusan dan Bagus Hermato. (2018). Implemnetasi Green Cosntitution di Indonesia: Jaminan Hak Konstitusional Pembangunan Lingkungan Hidup Berkelanjutan, Jurnal Konstitusi, 15(2). 306-326, Hal, 312. ${ }^{25}$ Indonesia, Undang Undang Dasar Negara Republik Indonesi Tahun 1945, Pasal 33 ayat (3)
} 


\section{Peraturan Perundang-Undangan}

Berpijak pada amanah rumusan-rumusan norma UUD NRI 1945 secara eksplisit mengamanahkan ikhtiar-ikhtiar negara harus mengarah pada rumusan kebijakan yang mengintegrasikan konsep perlindungan dan pembangunan berkelanjutan dalam peraturan perundang-undangan. karenanya, negara melalui lembaga-lembaga yang diserahi kewenangan membentuk peraturan perundang-undangan guna menderivasikan normanorma fundamental. 26

Dalam khazanah ilmu hukum upaya memahami kebijakan resmi negara dikenal dengan studi politik hukum, studi ini diarahkan untuk menelaah kebijakan yang telah diberlakukan dan akan diberlakukan guna mencapai tujuan negara. ${ }^{27}$ Bertautan dengan penelitian tersebut, menjadi fokus kajian meliputi peraturan perundang-undangan yang memiliki korelasi dengan pemanfaatan sumber daya alam, perlindungan lingkungan dan pembangunan berkelanjutan. ${ }^{28}$

Pilihan politik hukum pemerintah Indonesia atas perlindungan lingkungan dimulai dengan menggeser pendulum karakter tanggung jawab perusahaan, dari bersifat sukarela (responsibility) menjadi wajib (liability), ${ }^{29}$ mencakup ikhtiar mendudukkan secara tepat sifat dari tanggung jawab yaitu bersifat wajib. Hal ini sejalan dengan sanggahan kritis, bahwa konsep tanggung jawab yang dilakukan secara sukarela ialah contradiction in terminis atau kedua istilah tersebut bertentangan. ${ }^{30}$

Di dunia Internasional tanggung jawab perusahaan dikenal dengan istilah Corporate Sosial Responsibility yang sifatnya sukarela, sedangkan di Indonesia lahirnya konsensus untuk mengesahkan Undang-Undang Nomor 40 Tahun 2007 tentang Perseroan Terbatas selanjutnya pada akhir tahun 2020 diubah melalui mufakat Dewan Perwakilan Rakyat Republik Indonesia dan Presiden mengesahkan Undang-Undang Nomor 11 tahun 2020 tentang Cipta Kerja, meskipun telah dilakukan perubahan, namun hal ini tidak berdampak pada pengaturan tanggung jawab sosial dan lingkungkan perusahaan, sehingga keberadaan undang-undang tersebut telah menjadi tonggak pergeseran sifat CSR menjadi wajib, hal ini dapat ditelaah pada Pasal 109 UU Cipta Kerja, Tidak hanya merubah sifat CSR, undang-undang tersebut secara tegas juga telah merubah konsep tanggung jawab perusahaan yang dikenal secara global yaitu Tanggung Jawab Sosial dan menjadi Tanggung Jawab Sosial dan Lingkungan. ${ }^{31}$

\footnotetext{
${ }^{26}$ Indonesia, Pasal 20 ayat (1) Undang Undang Dasar Negara Republik Indonesia Tahun 1945 mengatur bahwa Dewan Perwakilan Rakyat (DPR) memegang kekuasaan membentuk undang-undang, pada ayat (2) diatur bahwa kekuasaan pembentukan undang-undang juga diserahkan kepada Presiden melalui pembahasan dan persetujuan bersama. Lihat juga Pasal 5 ayat (1) bahwa Presiden berhak mengajukan rancangan undang-undang kepada DPR.

${ }^{27}$ Sefriani dan Sri Wartini. (2017). Model Kebijakan Hukum Tanggung Jawab Sosial Perusahaan di Indonesia, Jurnal Hukum Ius Quia Iustum, 24(1), 1-28, Hal, 14.

${ }^{28}$ Radita Ajie. (2016). Batasan Pilihan Kebijakan Pembentuk Undang-Undang (Open Legal Policy) Dalam Pembentukan Peraturan PerundangUndangan Berdasarka Tafsir Putusan Mahkamah Konstitusi (Limit to Open Legal Policy in Legislation Making based On Constitutional Court Decision), Jurnal Legislasi Indonesia, 13(2), 111-120, Hal, 15.

${ }^{29}$ Mukti, M. (2018). Politik Hukum Pembentukan Peraturan Daerah Tentang Anggaran Pendapatan Dan Belanja Daerah. Al-Ishlah: Jurnal Ilmiah Hukum, 21(2), 75-84. Hal, 77.

${ }^{30}$ Nova Manda Sari. (2016). Urgensi Pengaturan Tanggung Jawab Sosial Perusahaan Dari Bersifat Sukarela (Voluntary) Menjadi Wajib (Mandatory), Rechtsvinding.

31 Sekar Atumningtyas dkk, (2017). Tinjauan Yuridis Terhadap Peraturan Perundang-Undangan Yang Mengatur Corporate Social Responsibility (Tanggung Jawab Sosial Perusahaan), Diponegoro Law Jurnal, 6(1), 1-12, Hal, 7.
} 
Pergeseran politik hukum yang merubah sifat CSR sejalan dengan riset yang dilakukan pada 1998 oleh Guningham dan Grabosky menunjukan faktor kelembagaan dan sistem hukum memainkan peran dalam mengoptimalkan pencapaian tujuan lingkungan dengan biaya rendah. ${ }^{32}$

Berpijak pada sabda Guningham dan Graboskky memperkokoh pilihan politik hukum dalam mengarahkan perbaikan lingkungan menggunakan istrumen hukum, di antaranya dengan rumusan norma yang menegaskan tanggung jawab perusahaan atas lingkungan melalui tanggung jawab perusahaan.

Adapun ikhtiar-ikhtiar kebijakan resmi negara terhadap komintmen pemenuhan hak lingkungan hidup yang sehat dan bersih serta pembangunan berkelanjutan atau peraturan perundang-undangan yang memiliki korelasi dan relevansi antara pemanfaatan sumber daya alam, lingkungan dan pembangunan berkelanjutan, terindetifikasi pada beberapa sistem norma sebagai berikut:

\section{Undang-Undang Nomor 39 Tahun 1999 tentang Hak Asasi Manusia}

Pada uraian sebelumnya dijelaskan salah satu hal yang harus dijamin dalam negara hukum ialah jaminan atas hak asasi manusia. Sebagai negara hukum, Indonesia menjamin hak asasi manusia melalui penderivasian norma yang secara khusus memuat norma jaminan atas hak asasi manusia, pada peraturan tersebut dirumuskan hak asasi manusia ialah seperangkat hak yang melekat pada hakikat dan keberadaan manusia sebagai mahkluk Tuhan Yang Maha Esa dan merupakan anugerah-Nya yang wajib dihormati, dijunjung tinggi dan dilindungi oleh negara, hukum, Pemerintah, dan setiap orang demi kehormatan serta perlindungan harkat dan martabat manusia.

Upaya mengatur lebih lanjut hak asasi manusia yang dijamin dalam konstitusi dilakukan dengan memberikan penjelasan cakupann hak-hak yang dikategorikan sebagai hak asasi manusia. Telaah atas peraturan perundangundangan hak asasi manusia memberikan penjelasan salah satu dimensi hak asasi manusia yang diatur dalam undang-undang tersebut ialah hak untuk memperoleh lingkungan hidup yang baik dan sehat. Bertalian dengan ketentuan atas lingkungan hidup yang baik dan sehat dirumuskan ketentuan yang memberikan rambu dalam pembangunan ekonomi nasional dilaksanakan dengan berdasarkan prinsip pembangunan berkelanjutan dan berwawasan lingkungan.

Sebagai upaya pemenuhan atas hak konstitusional memperoleh lingkungan hidup yang baik dan sehat, diatur lebih lanjut melalui perumusan peraturan perundang-undangan yang berkaitan dengan lingkungan hidup yaitu UndangUndang Nomor 32 Tahun 2009 tentang Perlindungan dan Pengelolaan Lingkungan Hidup.

\section{Undang-Undang Nomor 11 Tahun 2020 tentang Cipta Kerja aspek Perlindungan Lingkungan dan Pengelolaan Lingkungan Hidup}

\footnotetext{
32 I Gusti Ayu Ketut Rachmi Handayani. (2012). Green Constitution Sebagai Penguatan Norma Hukum Lingkungan Dan Pedoman Legal Drafting Peraturan Daerah Dalam Rangka Praktik-Praktik Tata Kelola Pemerintahan Yang Baik Di Daerah, Yustisia, 1(1), 130-144, Hal, 139.
} 
Semua mahfum, bahwa studi ilmu perundang-undangan memberikan penjelasan tidak lahir suatu kebijakan tanpa didasarkan pada kerangka atau dasar pemikiran perumusan suatu peraturan perundang-undangan, bertolak dari dalil tersebut, dipahami bahwa salah satu hal yang mendasari lahirnya undang-undang yang secara khusus untuk melindungi lingkungan hidup ialah menurunnya kualitas lingkungan hidup yang telah mengancam kelangsungan hidup manusia dan mahkluk hidup lainnya, serta meningkatnya pemanasan global yang memperparah kualitas lingkungan hidup.

Dasar pemikiran inilah yang mengatarkan para pembentuk undang-undang menyepakati politik hukum pemanfaatan sumber daya alam harus memperhatikan kesimbungan pembangunan untuk generasi yang akan datang. Batasan tentang pembangunan berkelanjutan dirumuskan ialah upaya sadar dan terencana yang memadukan aspek lingkungan hidup, sosial, dan ekonomi ke dalam strategi pembangunan untuk menjamin keutuhan lingkungan hidup serta keselamatan, kemampuan, kesejahteraan, dan mutu hidup generasi masa kini dan generasi masa depan. Pelaksanaan pembangunan keberlanjutan dilaksanakan melalui upaya pelestarian fungsi lingkungan hidup dengan cara menyusun rangkaian yang mengarah pada pemeliharaan terhadap kelangsungan daya dukung dan daya tampung lingkungan hidup. Adapun maksud pemeliharaan lingkungan hidup untuk mendukung perikehidupan manusia, makhluk hidup lain, dan keseimbangan antar keduanya.

Sebagai catatan, peraturan perundang-undangan tersebut memberikan batas pengertian sumber daya alam ialah unsur lingkungan hidup yang terdiri atas sumber daya hayati dan nonhayati yang secara keseluruhan membentuk kesatuan ekosistem. Bertalian dengan sumber daya alam yang pemanfaatannya melalui usaha dan/atau kegiatan memberikan dampak berupa perubahan pada lingkungan hidup, oleh karenanya atas usaha/kegiatan yang dilakukan sehingga menyebabkan perbuatan melanggar hukum berupa pencemaran dan/atau perusakan lingkungan hidup yang menimbulkan kerugian pada orang lain atau lingkungan hidup dibebani tanggung jawab berupa kewajiban membayar ganti rugi dan/atau melakukan tindakan tertentu.

\section{Undang-Undang Nomor 11 Tahun 2020 tentang Cipta Kerja aspek Tanggung Jawab Sosial dan Lingkungan}

Komitmen pemerintah untuk melaksanakan apa yang diamanahkan oleh UUD NRI 1945 berupa perlindungan dan pemenuhan hak atas lingkungan hidup yang baik dan sehat serta pembangunan berkelanjutan atas usaha/kegiatan pemanfaatan sumber daya alam. Pemerintah pada tahun 2007 melahirkan politik hukum atau kebijakan resmi negara yang didasarkan pada pertimbangan bahwa perekonomian nasional yang diselenggarakan berdasar atas demokrasi ekonomi dengan prinsip kebersamaan, efisiensi berkeadilan, berkelanjutan, berwawasan lingkungan, kemandirian, serta dengan menjaga keseimbangan kemajuan dan kesatuan ekonomi nasional, perlu didukung oleh kelembagaan perekonomian yang kokoh dalam rangka mewujudkan kesejahteraan masyarakat. Kemudian pada akhir tahun 2020 dilakukan perubahan melalui mufakat pengesahan Undang-Undang Nomor 11 Tahun 2020.

Secara khusus penegasan atas perjanjian negara memberikan dan memenuhi hak untuk memperoleh lingkungan sehat dan keberlanjutan yang 
juga tertuang dalam konsideran peraturan perundang-undangan, maka pemerintah memberikan tanggung jawab kepada perusahaan yang dikenal dengan tanggung jawab sosial dan lingkungan. Adapun maksud dari pemberian kewajiban tersebut sebagai wujud komitmen Perseroan untuk berperan serta dalam pembangunan ekonomi berkelanjutan guna meningkatkan kualitas kehidupan dan lingkungan yang bermanfaat, baik bagi Perseroan sendiri, komunitas setempat, maupun masyarakat pada umumnya. Penting menjadi catatan atas perubahan tersebut, bahwa pada aspek komitmen kewajiban pertanggung jawaban perusahaan masih mengusung semangat yang sama dengan tetap mengeuhkan kewajiban tanggung jawab sosial dan lingkungan terhadap perusahaan.

Pemberian beban kewajiban tanggung jawab sosial dan lingkungan bagi perseroan yang menjalankan kegiatan usahanya di bidang dan/atau berkaitan dengan sumber daya alam. Penganggaran pelaksanaan kewajiban tanggung jawab sosial dan lingkungan dianggarkan dan diperhitungkan sebagai biaya Perseroan yang pelaksanaannya dilakukan dengan memperhatikan kepatutan dan kewajaran. Agar Perseroan patuh terhadap kewajiban tanggung jawab sosial dan lingkungan, maka dirumuskan sanksi bagi perseroan yang tidak melaksanakan kewajiban, di mana sanksi didasarkan pada ketentuan peraturan perundang-undangan. Untuk melakukan kontrol terhadap pelaksanaaan tanggung jawab sosial dan lingkungan dilakukan dengan memberikan kewajiban dalam membuat laporan tahunan memuat pelaksanaan tanggung jawab sosial dan lingkungan.

Catatan penting dari undang-undang yang mendasari keberadaan perseroan di Indonesia, bahwa pemerintah menghendaki tanggung jawab perusahaan tidak hanya meliputi tanggung jawab sosial tetapi juga dipertegas tanggung jawab perusahaan atas lingkungan, dapat dipahami masuknya rumusan tanggung jawab perusahaan tidak hanya meliputi sosial tetapi juga lingkungan adalah penegasan pelaksanaan tanggung jawab diarahkan pada program lingkungan.

\section{Undang-Undang Nomor 21 Tahun 2014 tentang Panas Bumi, Undang- Undang Nomor 22 Tahun 2001 tentang Minyak dan Gas Bumi dan Undang-Undang Nomor 4 Tahun 2009 tentang Pertambangan Mineral dan Batubara}

Sayangnya, beberapa peraturan perundang-undangan lainnya belum secara tegas merumuskan kewajiban perusahaan terhadap tanggung jawab lingkungan, misalnya pada pilihan politik hukum kewajiban terhadap usaha/kegiatan perseroan berkenaan dengan pemanfaatan panas bumi, perseroan hanya diberikan kewajiban berupa tanggung jawab sosial perusahaan dan/atau pengembangan masyarakat sekitar.

Hal serupa juga nampak dalam pilihan politik hukum terkait pemanfaatan minyak dan gas bumi, tidak terdapat rumusan pasal yang secara tegas memberikan kewajiban kepada perseroan atas terhadap tanggung jawab lingkungan.

Belum sinkronnya komitmen dalam pemenuhan dan perlindungan atas hak memperoleh lingkungan yang baik dan sehata serta pembangunan berkelanjutan juga nampak pada politik hukum pemberian kewajiban terhadap 
perseroan yang melakukan pemanfaatan atas sumber daya alam pada usaha/kegiatan berkenaan dengan pertambangan mineral dan batu bara. Hal ini tercermin melalui rumusan pasal yang hanya mengatur bahwa kepada pemegang IUP (Izin Usaha Pertambangan) dan IUPK (Izin Usaha Pertambangan Khusus) wajib menyusun program pengembangan dan pemberdayaan masyarakat. Selanjutnya dijelaskan bahwa yang dimaksud dengan pemeberdayaan masyarakat ialah usaha untuk meningkatakan kemampuan masyarakat, baik secara individual maupun kolektif, agar menjadi lebih baik tingkat kehidupannya".

\section{Undang-Undang Nomor 25 Tahun 2007 tentang Penanaman Modal}

Berdasarkan hasil telaah atas peraturan perundang-undangan yang memiliki korelasi untuk mengatur politik hukum atas perlindungan dan pemenuhan hak atas lingkungan hidup yang baik dan sehat serta pembangunan berkelanjutan secara khusus terhadap pemanfaatan sumber daya alam. Jika membaca politik hukum di Indonesia maka salah satu kebijakan resmi negara yang memiliki relevansi untuk ditelaah yaitu peraturan tentang penanaman modal, dalam undang-undang modal termuat komitmen perlidungan lingkungan dan pembangunan keberlanjutan dirumuskan melalui asas penanaman harus berdasarkan asas berkelanjutan dan berwawasan lingkungan.

Sayangnya, dalam pasal yang mengatur kewajiban perusahaan tidak merumusakan kewajiban lingkungan sebagaimana dalam undang-undang perseroan terbatas, di mana undang-undang ini hanya mengatur bahwa penanaman modal diwajibkan penanaman modal berkewajiban menerapkan prinsip tata kelola perusahaan yang baik melaksanakan tanggung jawab sosial perusahaan.

Meskipun tidak mempertegas tanggung jawab perusahaan juga berkenaan tanggung jawab lingkungan, namun undang-undang tersebut pada pasal yang lian mempertegas komitmen perlindungan lingungan dengan mewajibkan tanggung jawab penanaman modal untuk menjaga kelestarian lingkungan hidup. Akan tetapi tanggung jawab ini hanya dimaksudkan pada saat selesai melakukan pemanfaatan sumber daya alam dan terbatas hanya pada sumber daya alam tidak terbarukan yang mengalokasikan dana secara bertahap untuk pemulihan lokasi yang memenuhi standar kelayakan lingkungan hidup, yang pelaksanaannya diatur sesuai dengan ketentuan peraturan perundangundangan.

Secara khusus dalam undang-undang penanaman modal terdapat rumusan pasal dan penjelasan yang menunjukan komitmen perlidungan lingkungan hidup dan pembangunan berkelanjutan, dimana untuk mendorong iklim persaingan usaha yang sehat, memperbesar tanggung jawab lingkungan dan pemenuhan hak dan kewajiban tenaga kerja, serta upaya mendorong ketaatan penanam modal terhadap peraturan perundang-undangan. Adapun penjelasan "asas berwawasan lingkungan" ialah penanaman modal yang dilakukan dengan tetap memperhatikan dan mengutamakan perlindungan dan pemeliharaan lingkungan hidup. Selain itu juga nampak pada penjelasan "tanggung jawab sosial perusahaan" adalah tanggung jawab yang melekat pada setiap perusahaan penanaman modal untuk tetap menciptakan hubungan yang serasi, 
seimbang, dan sesuai dengan lingkungan, nilai, norma, dan budaya masyarakat setempat.

\section{Undang-Undang Nomor 19 Tahun 2003 tentang Badan Usaha Milik Negara}

Tidak sinkron dan harmonisnya peraturan perundang-undangan juga nampak dalam undang-undang badan usaha milik negara yang notabene terdapat beberapa perseroan yang usaha/kegiatan bergerak pada pemanfaatan sumber daya alam. Sementara, undang-undang badan usaha milik negara hanya menyatakan bahwa maksud dan tujuan pendirian BUMN ialah turut aktif memberikan bimbingan dan bantuan kepada pengusaha golongan ekonomi lemah, koperasi, dan masyarakat. Dari uraian tersebut tidak mencerminkan komitmen politik hukum bahwa keberadaan badan usaha milik negara belum diorientasikan pada pembangunan ekonomi nasional yang memperhatikan aspek lingkungan hidup dan pembangunan keberlanjutan sebagaimana amanah pasal 33 ayat (4) UUD NRI 1945.

\section{Peraturan Pemerintah Nomor 23 Tahun 2010 tentang Pelaksanaan Kegiatan Usaha Pertambangan Mineral dan Batubara dan Peraturan Pemerintah Nomor 54 Tahun 2017 Tentang Badan Usaha Milik Daerah}

Sama hal nya dengan undang-undang yang mendasari kegiatan usaha pertambangan mineral dan batubara, peraturan turunan dalam hal ini peraturan pemerintah, juga tidak menunjukan penderifasian konstitusionalitas norma yang menghendaki green constitution. Belum terjewatahkannya norma yang mendasari green constitution tercermin pada pilihan politik hukum yang hanya mengatur bahwa keberadaaan pemegang IUP Operasi Produksi dan IUPK Operasi Produksi wajib menyampaikan laporan realisasi program pemberdayaan masyarakat setiap 6 (enam) bulan kepada Menteri, gubernur, atau bupati/walikota sesuai dengan kewenangannya. Jika tidak dilakukan akan dikenakan sanksi administartif.

Mendorong agar organ BUMD dalam membuat keputusan dan menjalankan tindakan dilandasi nilai moral yang tinggi dan kepatuhan terhadap peraturan perundang-undangan, serta kesadaran tanggung jawab sosial BUMD terhadap pemangku kepentingan maupun kelestarian lingkungan di sekitar BUMD.

Laporan tahunan memuat pelaksanaan tanggung jawab sosial dan lingkungan. Penggunaan Laba BUMD untuk Tanggung Jawab Sosial. BUMD melaksanakan tanggung jawab sosial dan lingkungan dengan cara menyisihkan sebagian laba bersih. Penggunaan laba untuk tanggung jawab sosial dan lingkungan sebagaimana dimaksud pada ayat (1) diprioritaskan untuk keperluan pembinaan usaha mikro, usaha kecil, dan koperasi.

\section{Peraturan Pemerintah Nomor 47 Tahun 2012 tentang Tanggung Jawab Sosial Dan Lingkungan Perseroan Terbatas}

Berbeda dengan peraturan perundang-undangan lainnya, peraturan yang secara khusus mengatur derifasi dari norma tentang tanggung jawab sosial dan lingkungan perseroan terbatas secara tegas mengatur bahwa sebagai subjek hukum, maka perseroan memiliki tanggung jawab sosial dan lingkungan. 
Lebih lanjut diatur tata cara pelaksanaan tanggung jawab sosial dan lingkungan disepakati sebagai suatu satu kewajiban bagi perseroan yang kegiatan usahanya dibidang atau berkaitan dengan sumber daya alam berdasarkan undang-undang baik di dalam maupun di luar lingkungan perseroan. Adapun perencanaan terkait dengan pelaksanaan tanggung jawab sosial dan lingkungan dimuat dalam rencana kerja tahunan perseroan yang telah mendapat persetujuan Dewan Komisaris atau RUPS. Dalam rencana kerja tahunan tersebut harus menyertakan rencana kegiatan dan anggaran untuk melaksanakan kewajiban berkaitan dengan tanggung jawab sosial dan lingkungan.

Sebagai bentuk komitmen politik hukum atas kehendak mewajibkan perseroan, maka diamanahkan jika suatu perseroan tidak menjalankan kewajiban berupa tanggung jawab sosial dan lingkungan akan dikenakan sanksi berdasarkan ketentuan peraturan perundang-undangan. Untuk mendukung perseroan dalam menunaikan kewajiban maka dalam undangundang tersebut diserahkan kewenangan kepada instansi yang berwenang kepada perseroan yang berperan dalam melaksanakan tanggung jawab sosial dan lingkungan.

\section{Peraturan Menteri Badan Usaha Milik Negara Nomor: Per- 05/MBU/2007 tentang Program Kemitraan Badan Usaha Milik Negara dengan Usaha Kecil dan Program Bina Lingkungan}

Berbeda dengan salah satu aturan yang menjadi acuan lahirnya politik hukum tanggung jawab perusahaan yang berstatus badan usaha milik negara, di mana pada judul menunjukkan adanya komitmen perlindungan terhadap lingkungan hidup untuk menjaga keberlanjutan pembangunan. Akan tetapi, pada rumusan norma tidak tercermin komitmen tersebut dengan melimitasi program bina lingkungan yang merupakan program pemberdayaan kondisi sosial masyarakat oleh BUMN melalui pemanfaatan dana dari bagian laba BUMN. Meskipun terdapat pasal yang kembali menegaskan kewajiban badan usaha milik Perum dan Persero wajib melaksanakan Program Kemitraan dan Program BL dengan memenuhi ketentuan-ketentuan yang diatur dalam Peraturan ini.

Selanjutnya dana Program Kemitraan dan Program Bina Lingkungan yang berasal dari penyisihan laba setelah pajak sebagaimana dimaksud pada ayat (1) dan ayat (2), disetorkan ke rekening dana Program Kemitraan dan Program Bina Lingkungan selambat-lambatnya 45 (empat puluh lima) hari setelah penetapan sebagaimana dimaksud pada ayat (3). Sayangnya, meskipun peraturan tersebut menyebutkan nomenklatur lingkungan tetapi hal ini berbeda dengan yang dimaksud dalam undang-undang perseroan terbatas bahwa lingkungan yang dimaksud ialah lingkungan hidup sebagaimana pada uraian di atas.

\section{SIMPULAN DAN SARAN}

Pengaturan tentang tanggung jawab perusahaan di Indonesia bersifat parsial, baik secara vertikal maupun horizontal dengan rumusan norma yang tampak belum senafas, tercermin pada beberapa peraturan perundangundangan belum menegaskan bahwa dimensi tanggung jawab perusahaan tidak hanya berdimensi tanggung jawab sosial semata, namun juga berdimensi 
tanggung jawab lingkungan. Sehingga, sukar untuk mengharapkan peraturan perundang-undangan yang ada saat ini menjadi dalil untuk melindungi lingkungan demi mencapai pembangunan berkelanjutan. Pada akhirnya, kita mufakat bahwa ikhtiar yang harus dilakukan pemerintah saat ini ialah reformulasi terhadap norma-norma yang memiliki korelasi dengan pemanfaatan sumber daya alam, perlindungan lingkungan dan pembangunan berkelanjutan dengan menggeser pendulum dimensi tanggung jawab perusahaan tidak semata tanggung jawab sosial, namun juga menegaskan tanggung jawab terhadap lingkungan mencakup rumusan norma tentang jumlah dan periode penganggaran biaya perlindungan lingkungan oleh setiap perusahaan.

\section{DAFTAR RUJUKAN}

Adinugroho Samuel Ronatio, Budiharto dan Priyono Joko. (2017). Pelaksanaan Tanggung Jawab Sosial dan Lingkungan PT. Pertamina Semaran (Persero) Ditinjau Dari Undang-Undang No 40 Tahun 2007 Tentang Perseroan Terbatas. Diponegoro Law Journal. 6(1).

Ajie Radita. (2016). Batasan Pilihan Kebijakan Pembentuk Undang-Undang (Open Legal Policy) Dalam Pembentukan Peraturan PerundangUndangan Berdasarka Tafsir Putusan Mahkamah Konstitusi (Limit to Open Legal Policy in Legislation Making based On Constitutional Court Decision), Jurnal Legislasi Indonesia, 13(2). DOI:

Andrzej Janowski. (2020). Philanthropy and the Contribution of Andrew Carnegie to Corporate Social Responsibility, MDPI, 13(155). DOI: https://doi.org/10.3390/su13010155

Atumningtyas Sekar, dkk, (2017). Tinjauan Yuridis Terhadap Peraturan Perundang-Undangan Yang Mengatur Corporate Social Responsibility (Tanggung Jawab Sosial Perusahaan), Diponegoro Law Jurnal, 6(1). DOI:

https://ejournal3.undip.ac.id/index.php/dlr/article/view/13883

Buana Andika Parwira, Ma'ruf Tria Abriana dan Aswari Aan. (2019). Harmonisasi Peraturan Perundang-Undangan terhadap Bentuk Perjanjian Melalui Telamarketing, Pleno Jure, 9(2). DOI: https://doi.org/10.37541/plenojure.v8i2

Detik Finance, Jumlah Perusahaan 10 Tahun Terakhir di Indoensia, $<$ https://finance.detik.com/berita-ekonomi-bisnis/d-3485474/ada398-juta-perusahaan-baru-di-ri-dalam-10-tahun-terakhir $>$ (diakses, 14 Maret 2020)

Gunningham Neil. (2009). The New Collaborative Enviromental Governance: The Localization of Regulation, Journal of Law and Society, 36(1). DOI: https://doi.org/10.1111/j.1467-6478.2009.00461.x

Handayani I Gusti Ayu Ketut Rachmi. (2012). Green Constitution Sebagai Penguatan Norma Hukum Lingkungan Dan Pedoman Legal Drafting Peraturan Daerah Dalam Rangka Praktik-Praktik Tata Kelola 
Pemerintahan Yang Baik Di Daerah, Yustisia, 1(1). DOI: https://doi.org/10.20961/yustisia.v1i1.10612

Jazuli Ahmad. (2015). Dinamika Hukum Lingkungan Hidup Dan Sumber Daya Alam Dalam Rangka Pembangunan Berkelanjutan. Rechtsvinding. 4(2). DOI: http://dx.doi.org/10.33331/rechtsvinding.v4i2.19

Kompas.com, 70 Persen Kerusakan Lingkungan akibat Operasi Tambang, https://regional.kompas.com/read/2012/09/28/17313375/70.Pers en.Kerusakan.Lingkungan.akibat.Operasi.Tambang (diakses, 20 Juli 2020)

Latipulhayat Atip. (2014). Roscoe Pound, Khazanah Padjajaran Jurnal Ilmu Hukum, 1(2). DOI: https://doi.org/10.22304/pjih.v1n2.a12

Likadja Jefry Alexander Ch. (2015). Memaknai "Hukum Negara (Law Throught State) dalam Bingkai "Negara Hukum (Rechstaat)", Hassanudin Law Review. 1(1). DOI: ttp://dx.doi.org/10.20956/halrev.v1i1.41

Mamonto Moch Andry W W. (2019). Legal Politics of Simplifying Political Parties in Indonesia (Case Study of 2004-2014), Substantive Justice Jurnal of Law, 2(1). DOI: https://substantivejustice.id/index.php/sucila/issue/view/4

Mandasari Nova. (2016). Urgensi Tanggung Jawab Sosial Perusahaan Dari Bersifat Sukarela (Voluntary) Menjadi Wajib (Mandatory), Jurnal Rechtsvinding.

Muhammad Cita Insaniah, Raharjo Santoso Tri dan Resnawaty Risan. (2018). Pelaksanaan Corporate Social Responsibility PT. Indonesia Power UPJP Kamojang, Social Work Jurnal, 2018, 8(2). DOI: https://doi.org/10.24198/share.v8i2.20080

Mukti, M. (2018). Politik Hukum Pembentukan Peraturan Daerah Tentang Anggaran Pendapatan Dan Belanja Daerah. Al-Ishlah: Jurnal Ilmiah Hukum, 21(2), 75-84. https://doi.org/10.33096/aijih.v21i2.18

Nikolaou Ioannis E., I. Evangelinos Konstatinos dan Allan. A. (2012). A Reverse Logistics Social Responsibility Evaluation Framework Based on the Triple Bottom Line Approach, Journal of Cleaner Production, 1-12. DOI: https://doi.org/10.3390/su13010155

Rauta Umbu and Siswanto Ari. (2018). Revitalization of Adat Law as an Instrument pf Social Engineering in Central Sumba, Jurnal Dinamika Hukum, 18(3). DOI: 10.20884/1.jdh.2018.18.3.2177

Ridwan Ita Rustiati, Dampak Industri Terhadap Lingkungan dan Sosial, Materi Kuliah PGSD UPI, Serang Banten, file:///Users//Downloads/15282745-1-SM.pdf (diakses, 25 Juni 2020).

Sametko FX. Adji. (2019). Menelusuri Akar Pemikiran Hnas Kelsen Tentang Stufenbautheorie Dalam Pendekatan Normatif-Filosofis, Jurnal Hukum Progresif, 7(1). DOI: https://doi.org/10.14710/hp.7.1.1-19 
Saraswati Nur Chanifah dan Fauzan Encik Muhammad, (2019). Konstitusionalitas Peraturan Perundang-Undangan Berbasis Syariah Di Indonesia. Simposium Hukum Indonesia, 1(1). DOI: https://journal.trunojoyo.ac.id/shi/article/view/6360

Sefriani dan Wartini Sri. (2017). Model Kebijakan Hukum Tanggung Jawab Sosial Perusahaan di Indonesia, Jurnal Hukum Ius Quia Iustum, 24(1). DOI: https://doi.org/10.20885/iustum.vol24.iss1.art1

Slamet Kusnu Goeniadhie, (2004), Harmonisasi Hukum dalam Perspektif Perundang-Undangan, Jurnal Hukum, 27(11). DOI: https://doi.org/10.20885/iustum.vol11.iss27.art8

Soemantri Sri, (1996) Fungsi Konstitusi Dalam Pembatasan Kekuasaa, Ius Quia Iustum Law, 6(3). DOI: https://doi.org/10.20885/iustum.vol3.iss6.art1

Suparto Susilowati, dkk. (2016). Harmonisasi dan Sinkronisasi Pengaturan Kelembagaan Sertifikasi Halal Terkait Perlindungan Konsumen Indonesia, Mimbar Hukum, 28(3). DOI: https://doi.org/10.22146/jmh.16674

Triansyah, W., Risma, A., \& Aswari, A. (2020). Alih Fungsi Lahan Sawah Tanah Redistribusi yang Diberikan Pemerintah. Qawanin Jurnal Ilmu Hukum, 1(1), 1-26.

Usman Abdurahman Supardi. (2018). Lingkungan Hidup Sebagai Subejk Hukum: Redefinisi Relasi Hak Asasi Manusi dan Hak Asasi Lingkungan Hidup Dalam Perspektif Negara Hukum. Legality, 26(1). DOI: https://ejournal.umm.ac.id/index.php/legality/article/view/6610

Weller Angeli. (2017). Exploring Pratitioners' Meaning of "Ethics", "Compliance", dan "Corporate Social Responsibility" Practices: A Communities of Practice Perspective, Business and Society. DOI: https://doi.org/10.1177/0007650317719263

Yusan I Gede dan Hermato Bagus. (2018). Implemnetasi Green Cosntitution di Indonesia: Jaminan Hak Konstitusional Pembangunan Lingkungan Hidup Berkelanjutan, Jurnal Konstitusi, 15(2). DOI: https://doi.org/10.31078/jk1524

\section{Peraturan}

Indonesia, Undang-Undang Nomor 32 Tahun 2009 tentang Perlindungan dan Pengelolaan Lingkungan Hidup, Lembaran Negara Republik Indonesia (LNRI) Tahun 2009 Nomor 140, dan Tambahan Lembaran Negara (TLN) Nomor 5059.

Indonesia, Undang-Undang Nomor 40 Tahun 2007 tentang Perseroan Terbatas, Lembaran Negara Republik Indonesia (LNRI) Tahun 2007 Nomor 106, dan Tambahan Lembaran Negara (TLN) Nomor 4756. 
Indonesia, Undang-Undang Nomor 21 Tahun 2014 tentang Panas Bumi, Lembaran Negara Republik Indonesia (LNRI) Tahun 2014 Nomor 217, dan Tambahan Lembaran Negara (TLN) Nomor 5585.

Indonesia, Undang-Undang Nomor 22 Tahun 2001 tentang Minyak dan Gas Bumi, Lembaran Negara Republik Indonesia (LNRI) Tahun 2001 Nomor 136, dan Tambahan Lembaran Negara (TLN) Nomor 4152.

Indonesia, Undang-Undang Nomor 4 Tahun 2009 tentang Pentambangan Mineral dan Batubara, Lembaran Negara Republik Indonesia (LNRI) Tahun 2009 Nomor 4, dan Tambahan Lembaran Negara (TLN) Nomor 4959.

Indonesia, Undang-Undang Nomor 25 Tahun 2007 tentang Penanaman Modal, Lembaran Negara Republik Indonesia (LNRI) Tahun 2007 Nomor 67, dan Tambahan Lembaran Negara (TLN) Nomor 4724.

Indonesia, Undang-Undang Nomor 19 Tahun 2003 tentang Badan Usaha Milik Negara, Lembaran Negara Republik Indonesia (LNRI) Tahun 2003 Nomor 70, dan Tambahan Lembaran Negara (TLN) Nomor 4297.

Indonesia, Undang-Undang Nomor 11 tahiun 2020 tentang Cipta Kerja, Lembaran Negara Republik Indonesia (LNRI) Tahun 2020 Nomor 245, Tambahan Lembaran Negara (TLN) Nomor 6753.

Indonesia, Peraturan Pemerintah Nomor 23 Tahun 2010 tentang Pelaksanaan Kegiatan Usaha Pertambangan Mineral dan Batubara, Lembaran Negara Republik Indonesia (LNRI) Tahun 2010 Nomor 29, dan Tambahan Lembaran Negara (TLN) Nomor 5111.

Indonesia, Peraturan Pemerintah Nomor 54 Tahun 2017 Tentang Badan Usaha Milik Daerah, Lembaran Negara Republik Indonesia (LNRI) Tahun 2017 Nomor 305, dan Tambahan Lembaran Negara (TLN) Nomor 6173.

Indonesia, Peraturan Pemerintah Nomor 47 Tahun 2012 tentang Tanggung Jawab Sosial Dan Lingkungan Perseroan Terbatas, Lembaran Negara Republik Indonesia (LNRI) Tahun 2012 Nomor 89, dan Tambahan Lembaran Negara (TLN) Nomor 5305.

Indonesia, Peraturan Presiden Nomor 59 Tahun 2017 tentang Pelaksanaan Pencapaian Tujuan Pembangunan Berkelanjuta, Lembaran Negara Republik Indonesia (LNRI) Tahun 2017 Nomor 136, dan Tambahan Lembaran Negara (TLN) Nomor.

Kementerian Badan Usaha Milik Negara, Peraturan Menteri Badan Usaha Milik Negara Nomor: Per-05/MBU/2007 tentang Program Kemitraan Badan Usaha Milik Negara dengan Usaha Kecil dan Program Bina Lingkungan. 